University of Nebraska - Lincoln

DigitalCommons@University of Nebraska - Lincoln

POLYACRYLAMIDE FOR SURFACE IRRIGATION TO INCREASE NUTRIENT-USE EFFICIENCY AND PROTECTWATER QUALITY

Rodrick D. Lentz

USDA-ARS

Robert E. Sojka

USDA-ARS

Charles W. Robbins

USDA-ARS

Dennis C. Kincaid

USDA-ARS

Dale T. Westermann

USDA-ARS

Follow this and additional works at: https://digitalcommons.unl.edu/usdaarsfacpub

Part of the Agricultural Science Commons

Lentz, Rodrick D.; Sojka, Robert E.; Robbins, Charles W.; Kincaid, Dennis C.; and Westermann, Dale T., "POLYACRYLAMIDE FOR SURFACE IRRIGATION TO INCREASE NUTRIENT-USE EFFICIENCY AND PROTECTWATER QUALITY" (2001). Publications from USDA-ARS / UNL Faculty. 567. https://digitalcommons.unl.edu/usdaarsfacpub/567

This Article is brought to you for free and open access by the U.S. Department of Agriculture: Agricultural Research Service, Lincoln, Nebraska at DigitalCommons@University of Nebraska - Lincoln. It has been accepted for inclusion in Publications from USDA-ARS / UNL Faculty by an authorized administrator of DigitalCommons@University of Nebraska - Lincoln. 


\title{
POLYACRYLAMIDE FOR SURFACE IRRIGATION TO INCREASE NUTRIENT-USE EFFICIENCY AND PROTECT WATER QUALITY
}

\author{
Rodrick D. Lentz, Robert E. Sojka, Charles W. Robbins, \\ Dennis C. Kincaid, and Dale T. Westermann \\ USDA-ARS Northwest Irrigation and Soils Research Lab., \\ Kimberly, ID 83341-5076
}

\begin{abstract}
Furrow irrigation systems have a greater application capacity, are less costly, and use less energy than sprinkler systems but furrow irrigation produces greater runoff, erosion, and deep percolation losses. Phosphorus (P) and nitrogen (N) losses are associated with runoff sediment, and can be minimized by eliminating irrigationinduced erosion. Excessive leaching of inorganic and organic solutes commonly occurs at the inflow region of furrow irrigated fields where infiltration opportunity times are longer. In one conservation practice, a high molecular weight, anionic polyacrylamide (PAM) is applied to advancing furrow stream flows at a concentration of $10 \mathrm{mg} \mathrm{L}^{-1}$. Because PAM stabilizes furrow soil and flocculates suspended sediment, we hypothesized that this treatment would reduce runoff losses of sediment, molybdate reactive $\mathrm{P}$ (MRP), total $\mathrm{P}, \mathrm{NO}_{3}-\mathrm{N}$, and chemical oxygen demand (COD). Polyacrylamide treatment may increase furrow infiltration in some soils. However, we hypothesized that because it permits higher initial inflows, PAM would not increase $\mathrm{NO}_{3}-\mathrm{N}$ or $\mathrm{Cl}$ leaching rela-
\end{abstract}


tive to conventional, constant inflow irrigation. To test the first hypothesis, all treatments had the same inflow regime. For hypothesis two, control inflows were a constant $15 \mathrm{~L} \mathrm{~min}^{-1}$; PAM treated inflows were cut back from 45 to $15 \mathrm{~L} \mathrm{~min}^{-1}$ after furrow advance. Irrigation runoff and percolation waters were sampled and analyzed. Polyacrylamide increased infiltration and decreased runoff, particularly early in the irrigations. Mean cumulative runoff sediment loss over $12 \mathrm{~h}$ was $11.86 \mathrm{~kg}$ for each control furrow vs $1.15 \mathrm{~kg}$ for PAM-treated furrows. The PAM reduced 12-h cumulative sediment losses in runoff by $90 \%$, MRP by $87 \%$, total P by $92 \%$, and COD by $85 \%$, relative to control furrows. Polyacrylamide had no field-wide, season-long effect on cumulative amounts of water, $\mathrm{NO}_{3}-\mathrm{N}$ or $\mathrm{Cl}$ leached. The PAM-technology effectively prevented soil nutrient losses, increased nutrient-use efficiency, and decreased $\mathrm{N}$ and $\mathrm{P}$ loads in irrigation return flows and receiving surface waters.

\section{INTRODUCTION}

Irrigated agriculture stabilizes world food and fiber production by increasing yields relative to rainfed agriculture and reducing risks associated with crop production (Bucks et al., 1990). Mineralized or applied nutrients must remain in the root zone to be effectively utilized by plants. Soluble nutrients displaced from the root zone by lateral and downward moving water can enter groundwater. $\mathrm{Nu}-$ trients dissolved or desorbed from surface soil particles and those that remain attached to soil can enter the furrow stream and be transported via irrigation return flows to surface waters. Public concern over irrigation impacts on surface and groundwater quality recently has focused on sediments, nutrients, dissolved salts, and toxic organic compounds (Bucks et al., 1990).

Runoff and drainage losses from furrow irrigation are greater than from other surface methods and sprinkler irrigation. Compared to level basin or sprinkler irrigation, furrow irrigation produces a less uniform water application. Opportunity time for infiltration is longer in furrow soils near the inflow ends, hence these soils receive more water and experience a greater leaching potential than furrow soils near outflow ends (Childs et al., 1993). Channeled concentrated flow in furrows is erosive (Koluvek et al., 1993) but furrow runoff is tolerated in order to improve water application uniformity (Bishop et al., 1967). Compared to level basin or sprinkler irrigation, furrow irrigation produces a greater displacement or removal of soil and nutrients from the plant locale, and increased transport of sediment and nutrients to surface waters in return flow. However, owing to the lower installation and energy costs, high application capacity, and reduced patho- 
gen infestation associated with furrow irrigation (Bishop et al., 1967), it is commonly used in the U.S. and other nations.

Furrow irrigated soils in the northwestern U.S. are highly erosive (Berg and Carter, 1980). They have low organic matter content and exhibit mineral characteristics which tend to inhibit aggregate stability, especially under the rapid wetting and shear forces present in irrigation furrow streams (Kemper et al., 1985). Thirty to sixty percent of the water applied leaves furrow irrigated fields as runoff (Lentz et al., 1992). Irrigation runoff has negatively impacted surface streams in southern Idaho through contributions of sediment, nutrient, and pesticides (IDHW-DEQ, 1994).

\section{Nutrient Fluxes into Irrigation Runoff and Drainage Waters}

Furrow irrigation moves soluble or particulate organic matter, $\mathrm{N}$, and $\mathrm{P}$ from soil to drainage and runoff, which increase nutrient loading in surface waters (Carter et al., 1971; Fitzsimmons et al., 1972; Mackenzie and Viets, 1974; Heathwaite and Johnes, 1996). Subsurface drainage losses of nitrogen under irrigation tracts in southern Idaho are significant, although some of this nitrogen may originate from nonagricultural sources, such as residential septic systems (Carter et al., 1971). Nitrate- $\mathrm{N}$ is the main form of $\mathrm{N}$ lost in drainage water (Carter et al., 1971; Fitzsimmons et al., 1972), although organic-N losses may be an important component (Mackenzie and Viets, 1974). Nitrate-, $\mathrm{NH}_{4^{-}}$and organic-N can be dissolved or entrained in furrow runoff (Fitzsimmons et al., 1972). Large increases in runoff inorganic- $\mathrm{N}$ concentrations occur when fertilizers are applied to fields in irrigation water, but not all high $\mathrm{N}$-loss events are associated with such operations (Fitzsimmons et al., 1972).

Carter et al. $(1971,1974)$ reported that south-central Idaho surface irrigated tracts were a net sink for total $\mathrm{P}$ and ortho-P loads entering the tracts in irrigation source water. Irrigation runoff had higher $\mathrm{P}$ concentrations than source water but return flow volumes were a small fraction $(14 \%)$ of the total source water volume diverted from the Snake River, and $\mathrm{P}$ concentrations in the groundwater-derived return flow contributions (13\% of tract supply flow volume) were lower than that of the source water. Carter concluded that ortho-P was being removed from irrigation water as it drained through, and reacted with, the calcareous soils. In contrast, Fitzsimmons et al. (1972) reported that groundwater ortho-P and total $\mathrm{P}$ concentrations increased relative to source water in a southwestern Idaho irrigated tract. Carter sampled groundwater discharged from drainage tunnels cut into basalt bedrock in addition to tile drains, whereas, Fitzsimmons collected only tile drain water.

Nutrient concentrations in irrigation runoff occur in dissolved form, are associated with soil particles, or occur as organic particulates and colloids. Total $\mathrm{P}$ 
and organic-N forms are largely associated with transported sediment and organic particles or colloids in furrow runoff (Carter et al., 1974; Carter and Bondurant, 1976). Furrow erosion and transport processes and runoff sediment load substantially determine the concentrations of these nutrient components in runoff (Carter et al., 1974; Brown, 1985; Bjorneberg et al., 1999). Clay and organic matter adsorb more $\mathrm{P}$ than other soil materials. The stream sediment clay: soil ratio, also called the enrichment ratio, and the total sediment load largely determine the total $\mathrm{P}$ in runoff (Carter et al., 1974). The $\mathrm{P}$ enrichment ratio increases as the proportion of clay and organic matter in the sediment load increases, and declines as sediment increases, owing to the decrease in the proportion of fine to coarse particles in sediments produced from escalating erosion regimes (Logan, 1982).

Dissolved nutrient concentrations, ortho- $\mathrm{P}, \mathrm{NO}_{3}-\mathrm{N}$ and $\mathrm{NH}_{4}-\mathrm{N}$ in furrow runoff and subsurface drainage water result from the reaction of water with the soil surface and decaying crop residues, including dispersed and detached particles that become suspended in the flow (Logan, 1982). Water soluble nutrients dissolve in the water and desorb (eg. ortho- $\mathrm{P} \mathrm{NH}_{4}-\mathrm{N}$ ) from soil surfaces and diffusion/advection processes move dissolved materials from soil/sediment pores into the furrow stream or drainage flow (Logan, 1982). In furrows, the quantity of nutrient ions made available via this process decreases with increasing time of exposure to the stream (Oloya and Logan, 1980). The quantity of ortho-P desorbed was correlated with the soil test $\mathrm{P}$ concentration (Westermann et al., 1999). Once it enters the furrow stream, a fraction of the dissolved ortho- $\mathrm{P}$ and $\mathrm{NH}_{4}-\mathrm{N}$ may adsorb to sediment present in the flow. The dissolved ions eventually reach an equilibrium concentration in the runoff (Logan, 1982). During an irrigation, erosional processes such as channel abrasion, sidewall collapse, and migrating headcuts expose fresh soil surfaces to the stream flow. This soil contributes additional nutrients to the flow.

\section{Polyacrylamide Technology in Furrow Irrigation}

Furrow irrigation polyacrylamide (PAM) technology was developed as a solution to high erosion rates associated with this irrigation practice on coarse and medium textured soils (Lentz et al., 1992). Early irrigation studies with PAM focused on its sediment loss and infiltration effects. Experiments on a number of different soils with varying furrow slopes and lengths in southern Idaho demonstrated that the standard PAM application reduces soil loss from furrows by an average of $94 \%$ and increases net infiltration into newly formed furrows by $15 \%$ (Lentz and Sojka, 1994). The standard method applies an optimal $10 \mathrm{mg}$ PAM $\mathrm{L}^{-1}$ water $(10 \mathrm{ppm})$ to irrigation inflows only during the furrow advance stage, i.e. when the water stream first advances down the furrow, and before runoff begins (Lentz et al., 1992). After the furrow advance, PAM application is curtailed 
and untreated inflows are used for the remainder of the irrigation set. Polyacrylamide dissolved in the inflow water is adsorbed and irreversibly bound to soil particle and aggregate surfaces in the furrow wetted perimeter (Mitchell, 1986; Malik and Letey, 1991; Lentz et al., 1992; Letey, 1994).

The PAM commonly used is a water soluble, linear anionic polyacrylamide copolymer (Barvenik, 1994) which was found to be most effective for furrow erosion control (Lentz and Sojka, 2000a). The PAM has a molecular weight of $12-15 \mathrm{Mg} \mathrm{mol}^{-1}$ and charge-density of $8-35 \%$. This material has demonstrated a remarkable ability to stabilize dry soil aggregates under rapid inundation and flow shear, flocculate fine soil particles suspended in flows, and coarsen aggregate size characteristics in the furrow system. These PAM-induced impacts result in reduced furrow erosion and increased infiltration (Terry and Nelson, 1986; Lentz, 1995; Sojka et al., 1998b). Barvenik (1994) concluded that anionic PAM applications in irrigation furrows posed little threat to organisms or the environment.

A detailed description of PAM field application and general technical and practical guidelines have been discussed elsewhere (Lentz, 1995; Lentz et al., 1995; Sojka and Lentz, 1997). Research has investigated field efficacies of different PAM application rates (Lentz and Sojka, 1994) and strategies (Lentz and Sojka, 2000b). Lentz et al. (2000a) studied the effects of polymer molecular weight, charge type and density characteristics on field erosion and infiltration results. Other studies have focused on PAM's impacts on furrow infiltration (Trout et al., 1995; Sojka et al., 1998a,b), multiple treated irrigations (Sojka et al., 1998b), and surge irrigation applications (Yonts et al., 1998).

Two field studies were conducted to test the hypothesis that a PAM-based furrow irrigation management approach could reduce sediment, soil organic matter (estimated by COD), and nutrient losses from soils in furrow irrigated fields without increasing leaching losses of soluble nutrients. The PAM irrigation management strategy can take advantage of PAM's erosion control capabilities, i.e. higher initial inflows can be turned into PAM-treated furrows than to untreated furrows. One study examined the effect of PAM treatment on soil and nutrient field losses. Another study determined PAM management effects on field leaching losses relative to conventional furrow irrigation.

\section{MATERIALS AND METHODS}

Field studies were conducted at the USDA-ARS Northwest Irrigation and Soils Research Laboratory at Kimberly, Idaho, USA. Dry bean (Phaseolus vulgaris L. 'Viva Pink') or silage corn (Zea mays L.) was planted on Portneuf silt loam (coarse-silty, mixed superactive, mesic Durinodic Xeric Haplocalcids). The seedbed was prepared with disk and roller harrow. Surface soil texture was silt loam (10\% clay, $70 \%$ silt), organic matter was $10-13 \mathrm{~g} \mathrm{~kg}^{-1}$, cation exchange 
capacity was $190 \mathrm{mmol}_{\mathrm{c}} \mathrm{kg}^{-1}$, saturated-paste-extract electrical conductivity (EC) was $0.7 \mathrm{dS} \mathrm{m}^{-1}$, ESP was 1.5, $\mathrm{pH}$ was 7.7, and calcium carbonate equivalent was $5 \%$. Furrows were approximately $175 \mathrm{~m}$ long, with a $1.6 \%$ slope. Furrows were shaped with a weighted wedge-shaped forming tool. To avoid infiltration differences between wheel-tracked and nonwheel-tracked furrows, only trafficked furrows were irrigated and monitored.

Irrigation water diverted from the Snake River contained $0.10 \mathrm{mg} \mathrm{L}^{-1}$ total $\mathrm{P} ; 0.03 \mathrm{mg} \mathrm{L}^{-1}$ molybdate reactive $\mathrm{P} ; 11.8 \mathrm{mg} \mathrm{L}^{-1} \mathrm{COD}$, and $<0.02 \mathrm{mg} \mathrm{L}^{-1}$ $\mathrm{NO}_{3}-\mathrm{N}$, and had an EC of $0.5 \mathrm{dS} \mathrm{m}^{-1}$ and SAR of 0.5. A gated pipe conveyed water to the each furrow and adjustable spigots controlled inflow rates. Plots were irrigated five times during each irrigation season. Furrow inflows and outflows were monitored, and runoff sediment concentrations were measured throughout each irrigation. Measurements were made at one-half hour intervals early in the irrigation, and every hour or every several hours in the latter half of the irrigation after outflows and sediment loads had stabilized. Inflows were measured by filling a known volume per unit time, and outflows were measured with v-notch flumes (Trout and Mackey, 1988). Sediment was measured using Imhoff cones (Sojka et al., 1992). Details of the flow and sediment monitoring procedure were given by Lentz et al. (1992). The experimental design was a complete randomized block, with three replications. Furrow runoff, component loads, and infiltration were computed with the computer program, WASHOUT (Lentz and Sojka, 1995). Net infiltration was calculated as the difference between total inflow and total outflow.

The water soluble, anionic PAM copolymer employed had a molecular weight of $12-15 \mathrm{Mg} \mathrm{mol}^{-1}$ and charge-density of $18 \%$. Granular PAM was used to prepare a 1200 or $2400 \mathrm{mg} \mathrm{L}^{-1}$ (1200 or $2400 \mathrm{ppm}$ ) aqueous stock solution. Stock solutions were prepared by slowly sprinkling (over a $20-30 \mathrm{~min}$ period) PAM into tap water that was vigorously and continuously agitated with a rotating bladed stirrer. Positive displacement pumps injected the stock solution into the inflow end of PAM-treated furrow streams at an appropriate rate to meet the PAM concentration target.

\section{Runoff Nutrient Loss Study}

This study compared irrigation furrow inflow and outflow rates, and runoff nutrient concentrations and losses from a control and two PAM treatments. Control furrow streams contained no PAM. Polyacrylamide was applied continuously at $1 \mathrm{mg} \mathrm{L}^{-1}$ in a continuous PAM 1-ppm treatment (Cont PAM1). In the Standard PAM-10 treatment (Std PAM10), PAM was applied at $10 \mathrm{mg} \mathrm{L}^{-1}$ only during the advance phase. Polyacrylamide injection in the Std PAM-10 was curtailed at an average $111 \mathrm{~min}$ after the irrigation began, ie. shortly after the end of the advance phase, and untreated water was used for the remainder of the irrigation set. A 
cutback irrigation strategy was used for all treatments. Initial irrigation inflows were set to $23 \mathrm{~L} \mathrm{~min}^{-1}$ to move water across the field quickly, then flows were manually cut back to $15 \mathrm{~L} \mathrm{~min}^{-1}$ to reduce runoff. Irrigations were 8 to 24 hours in duration.

Irrigation inflows and three irrigation runoff samples from each furrow were collected for nutrient analysis. Runoff samples were taken from outflow monitoring flumes. Runoff nutrient content was not determined for the last irrigation of the season. Since $97 \%$ of the field's sediment losses occurred in the first four irrigations, we believed nutrient losses produced by the final irrigation were also very small. The first runoff sample was collected after all PAM furrows had completed their advance but before PAM application was stopped. The second was taken $0.5 \mathrm{~h}$ after PAM application had ceased, and the third was taken $4.5 \mathrm{~h}$ later. Thus, sampling times differed with each irrigation, but all were collected during the periods: 1 to $3.5 \mathrm{~h} ; 4.5$ to $7 \mathrm{~h}$; and 7.5 to $10 \mathrm{~h}$ into the irrigation. Runoff samples were stored at $2^{\circ} \mathrm{C}$. for $<8$ days before being analyzed. Unfiltered samples were analyzed for total P (Greenberg et al., 1992), molybdate-reactive-P or MRP (Watanabe and Olsen, 1965), and chemical oxygen demand, COD (American Public Health Association et al., 1971). Nitrate-N was determined on filtered samples (Whatman 42 filter, $2.0 \mathrm{mM}$ potassium benzoate eluent and liquid ion chromatography).

Irrigation treatment comparisons and duration graphs were based on a 12-h irrigation length. WASHOUT (Lentz and Sojka, 1995) computed runoff and pollutant loads using outflow and sediment records (12 measurements per irrigation) and runoff nutrient concentrations ( 3 per irrigation). Runoff nutrient loads were computed under assumption that runoff component concentrations were constant between sampling intervals. The 12-h values for the first irrigation (an 8-h irrigation) were computed assuming that no change in flow and constituent concentrations occurred after $8 \mathrm{~h}$. Previous experience indicated that this was a valid premise. Duration graph values are means from the four monitored irrigations. Confidence limits $(P=0.05)$ for duration treatment means were based on the Student's $t$ distribution (Snedecor and Cochran, 1980).

\section{Field Leaching Study}

Soil water percolating below $120 \mathrm{~cm}$ depth was monitored during the irrigation season for conventional vs PAM-managed irrigation furrows. Conventional furrows were irrigated with $15 \mathrm{~L} \mathrm{~min}^{-1}$ untreated inflows for the entire irrigation. Polyacrylamide furrows were irrigated with $10 \mathrm{mg} \mathrm{L}^{-1}$ PAM-treated inflows at $45 \mathrm{~L} \mathrm{~min}^{-1}$ during the furrow advance phase, then PAM injection ceased and inflows were reduced to $15 \mathrm{~L} \mathrm{~min}^{-1}$ for the remainder of the irrigation. Twelve monitoring sites were installed, four in each of three blocks, at both the 
upper and lower portion of the plot (30 and $150 \mathrm{~m}$ along 180-m-long furrows). Soil water percolation losses were measured throughout the irrigation season. Length of irrigation sets were the same for both treatments in the abbreviated 1996 irrigation season. However, in 1997 and 1998, irrigation set times were varied between treatments, to ensure that average net infiltration for both treatments was equal for any given irrigation.

We installed 36 vacuum extraction soil water percolation samplers, three at each monitored site (Lentz et al., 1998a). Instruments were installed in the vertical face of a backhoe trench dug beside the monitored furrow. The vacuum extraction system designed for this experiment was discussed in detail by Lentz et al. (1998a) and Kincaid and Lentz (1999). A field deployed precision vacuum pump and tank were connected via a gas dryer to a polyethylene tube main line that ran the length of the field. Branch lines off the mainline supplied upper and lower field positions via manifolds at each site. Each manifold supplied 1-L vacuum flasks connected to individual samplers. In 1997, a Bourdon-tube pressure switch and Hg U-tube manometer regulated system vacuum in main and branch lines. For 1998, we designed an electronic vacuum controller and data logger program that set extraction vacuum independently for each site according to local soil water conditions. The line extractor-soil suction ratio was 1.4 to 1.5 (Lentz et al., 1998a).

Instrument installation was completed by late August, 1996. Prior to irrigation in $1996, \mathrm{CaCl}_{2}\left(112 \mathrm{~kg} \mathrm{ha}^{-1}\right)$ was applied to the surface of fallow plots as a drainage marker. Two irrigations were monitored during September 1996. In 1997, $168 \mathrm{~kg} \mathrm{ha}^{-1}$ urea was applied and plots were planted to a short-season corn. Five irrigations were monitored beginning 16 July. Water sample volumes were measured and collected every 1-2 days, treated with boric acid to curtail biologic activity, and stored at $2^{\circ} \mathrm{C}$. for later chemical analysis. Sample $\mathrm{NO}_{3}-\mathrm{N}$, and $\mathrm{Cl}$ were determined with standard flow injection analysis (FIA) procedures. The mean constituent percolation and mass loss measurements at each site were summed over the season and an ANOVA with Tukey test (SAS Institute Inc., 1988) was employed to compute treatment mean separations $(P=0.05)$. Field wide losses were computed as the mean of upper and lower field values.

\section{RESULTS AND DISCUSSION}

\section{Runoff Nutrient Losses}

Irrigation duration data showed significant differences between control and PAM-treated furrows with regard to hydraulic properties, runoff pollutant concentrations, and loading. Runoff rates did not differ between treatments during the first hour of the runoff period (Fig. 1). In the second hour, treatment runoff rates diverged, with control furrows having significantly higher runoff rates than 

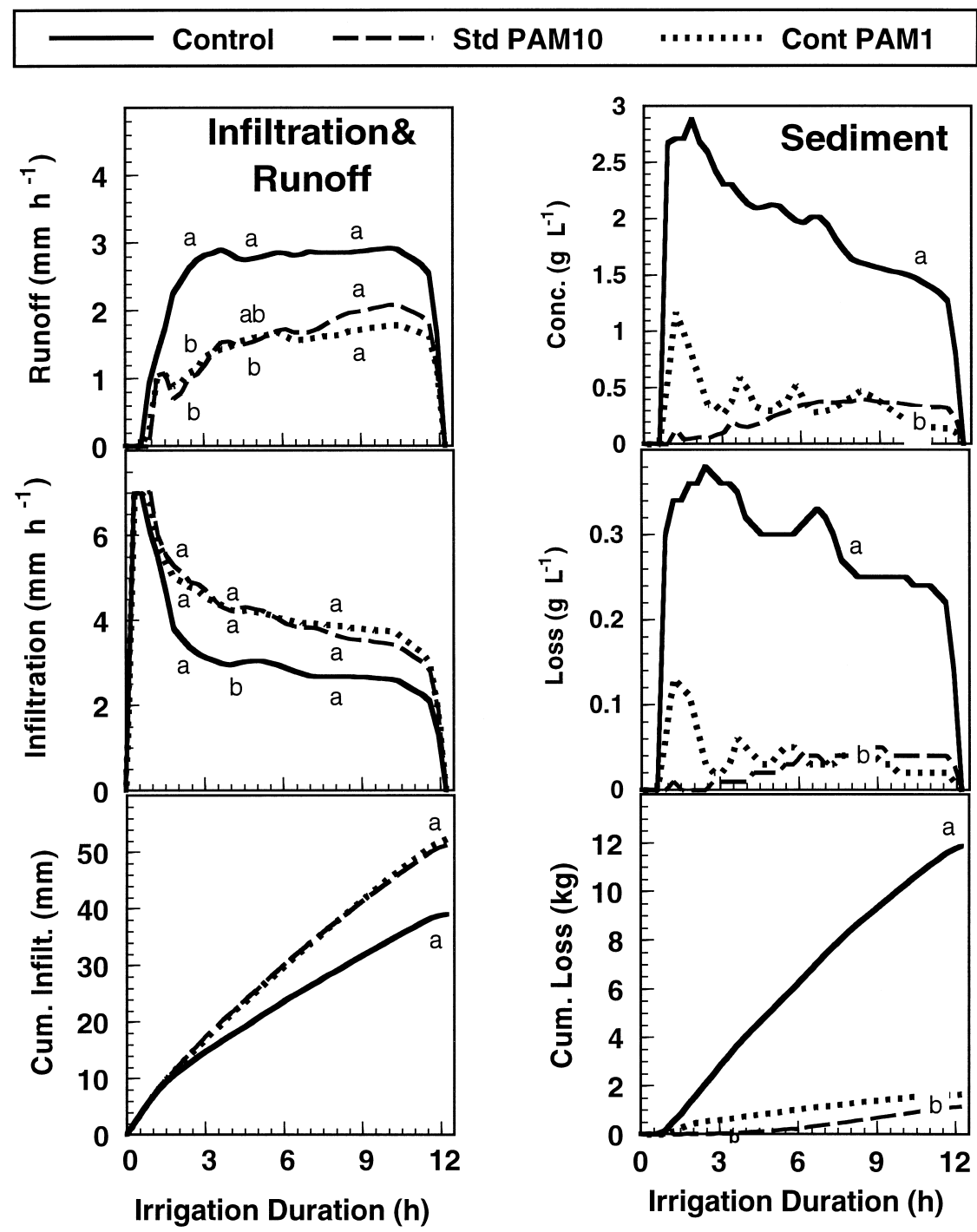

Figure 1. Infiltration and runoff (on left), and sediment concentrations and losses (on right) per furrow. Treatments included a control, $10 \mathrm{mg} \mathrm{L}^{-1}$ PAM applied during advance only (Std PAM10), and PAM applied continuously at $1 \mathrm{mg} \mathrm{L}^{-1}$ (Cont PAM1). Similar letters indicate nonsignificant differences $(\mathrm{P}=0.05)$ between treatment values. 
PAM-treated furrows (Fig. 1). Infiltration rates followed runoff in a similar but reversed pattern. No significant differences between treatments were indicated for runoff and infiltration after furrow streams flowed for $6 \mathrm{~h}$, though the mean treatment values from later in the irrigation were only slightly different from the 6-h values. Thus PAM's infiltration effects continued but became less consistent with time. This suggested that the PAM-stabilized soil structure in the furrow surface may have begun to break down over time, and/or that the depositional seal formed under PAM may have begun to clog late in the irrigation set, reducing seal permeability (Sojka et al., 1998a).

During the irrigations, sediment concentration and mass losses for control furrows were 4 to $100 \times$ greater than those for Std PAM10 furrows, and 2.5 to $10 \times$ greater than that of Cont PAM1 furrows (Fig. 1). Mean 12-h cumulative sediment loss for controls was $10 \times$ greater than that of Std PAM10 and $7 \times$ greater than that of Cont PAM1 furrows. The 12-h cumulative sediment loss per control furrow was $11.86 \mathrm{~kg}$ vs $1.15 \mathrm{~kg}$ for Std PAM10 furrows, i.e. $609 \mathrm{~kg} \mathrm{ha}^{-1}$ vs $59 \mathrm{~kg} \mathrm{ha}^{-1}$.

Changes in runoff concentration and mass loss for control and PAM treatments followed a similar pattern for all components except $\mathrm{NO}_{3}-\mathrm{N}$. Concentration and mass loss values for nutrients (except $\mathrm{NO}_{3}-\mathrm{N}$ ) paralleled that for sediment (Figs. 1, 2 and 3). At any given time during the irrigation, runoff concentrations and mass losses of these components were about 4 to $10 \times$ greater in control furrows than in Std PAM10 and Cont PAM1 furrows. The exception to this pattern came for Cont PAM1 furrows during the first $7 \mathrm{~h}$ of each irrigation. During that period, control values were 1.2 to $3 \times$ that of Cont PAM1 furrows, and the differences between control and Cont PAM1 values, in most cases, were not significant. The similarity in duration patterns suggests that COD, MRP, and total P components were closely associated with sediment.

Mean 12-h cumulative losses of MRP, total P, and COD were significantly greater for controls than either PAM treatment. Cumulative mass losses of controls were 7 to $14 \times$ the Std PAM10, and 3 to $6 \times$ the Cont PAM1 values (Figs. 1, 2 and 3). Thus, compared to controls, Std PAM10 reduced 12-h cumulative mass losses of sediment by $90 \%$, COD by $85 \%$, MRP by $87 \%$, and total P by $92 \%$. These values were similar to those reported for 24-h irrigations (Lentz et al., 1998b).

No significant differences between control and PAM treatments were observed for duration runoff $\mathrm{NO}_{3}-\mathrm{N}$ concentration, mass losses, or cumulative losses (Fig. 2). The peak in $\mathrm{NO}_{3}-\mathrm{N}$ concentrations observed at mid-irrigation resulted from an anomalously high value in a single furrow, and hence was not statistically significant. Runoff $\mathrm{NO}_{3}-\mathrm{N}$ concentrations during the irrigation were unrelated to that of sediment. In contrast, runoff COD, MRP, and total P concentrations appeared to be dependent on runoff sediment. A correlation analysis of the runoff sediment vs nutrient concentration data confirmed these observations (Lentz et al., 


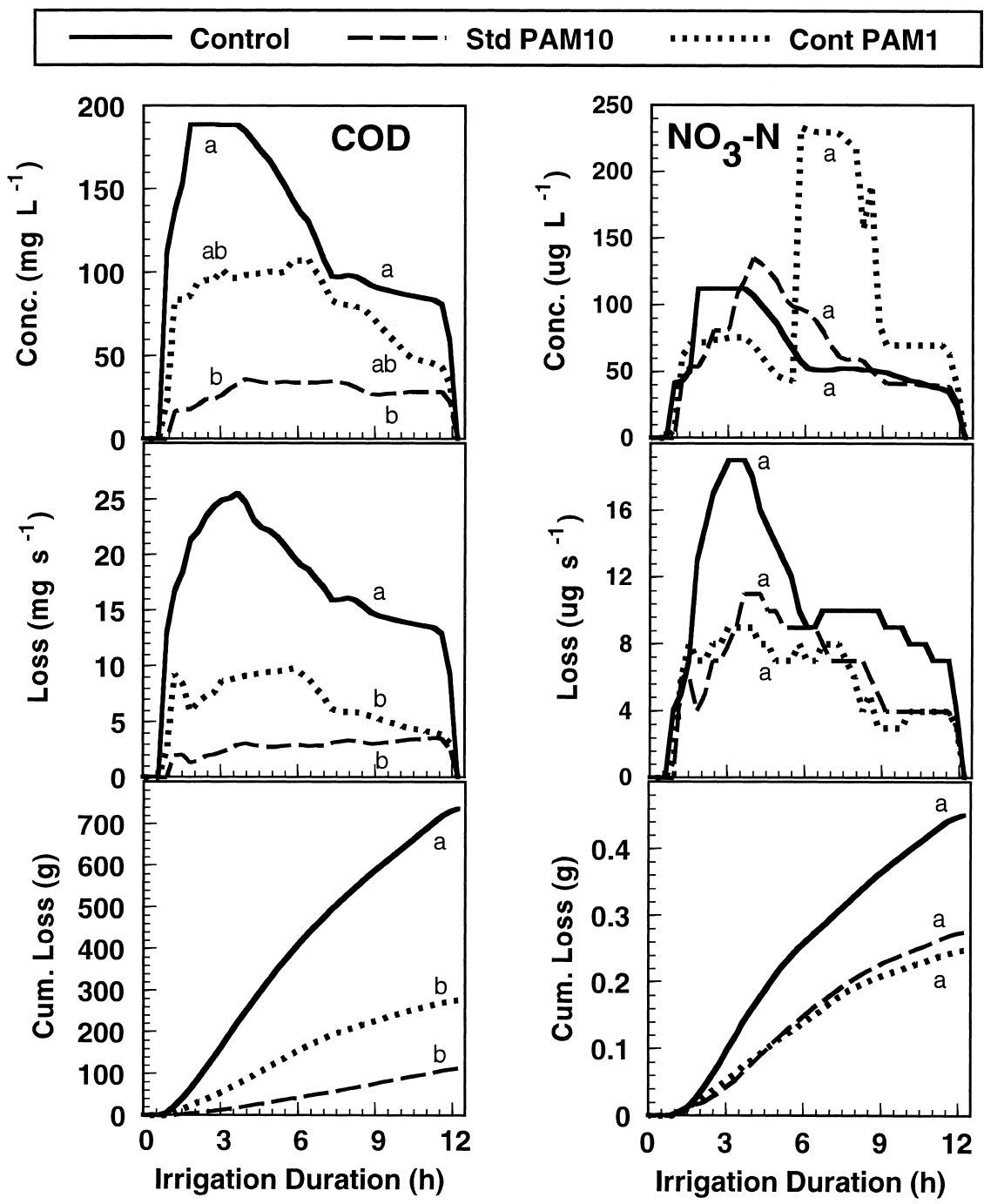

Figure 2. Chemical oxygen demand (COD on left) and $\mathrm{NO}_{3}-\mathrm{N}$ (on right) concentrations and losses per furrow. Treatments included a control, $10 \mathrm{mg} \mathrm{L}^{-1}$ PAM applied during advance only (Std PAM10), and PAM applied continuously at $1 \mathrm{mg} \mathrm{L}^{-1}$ (Cont PAM1). Similar letters indicate nonsignificant differences $(\mathrm{P}=0.05)$ between treatment values. 


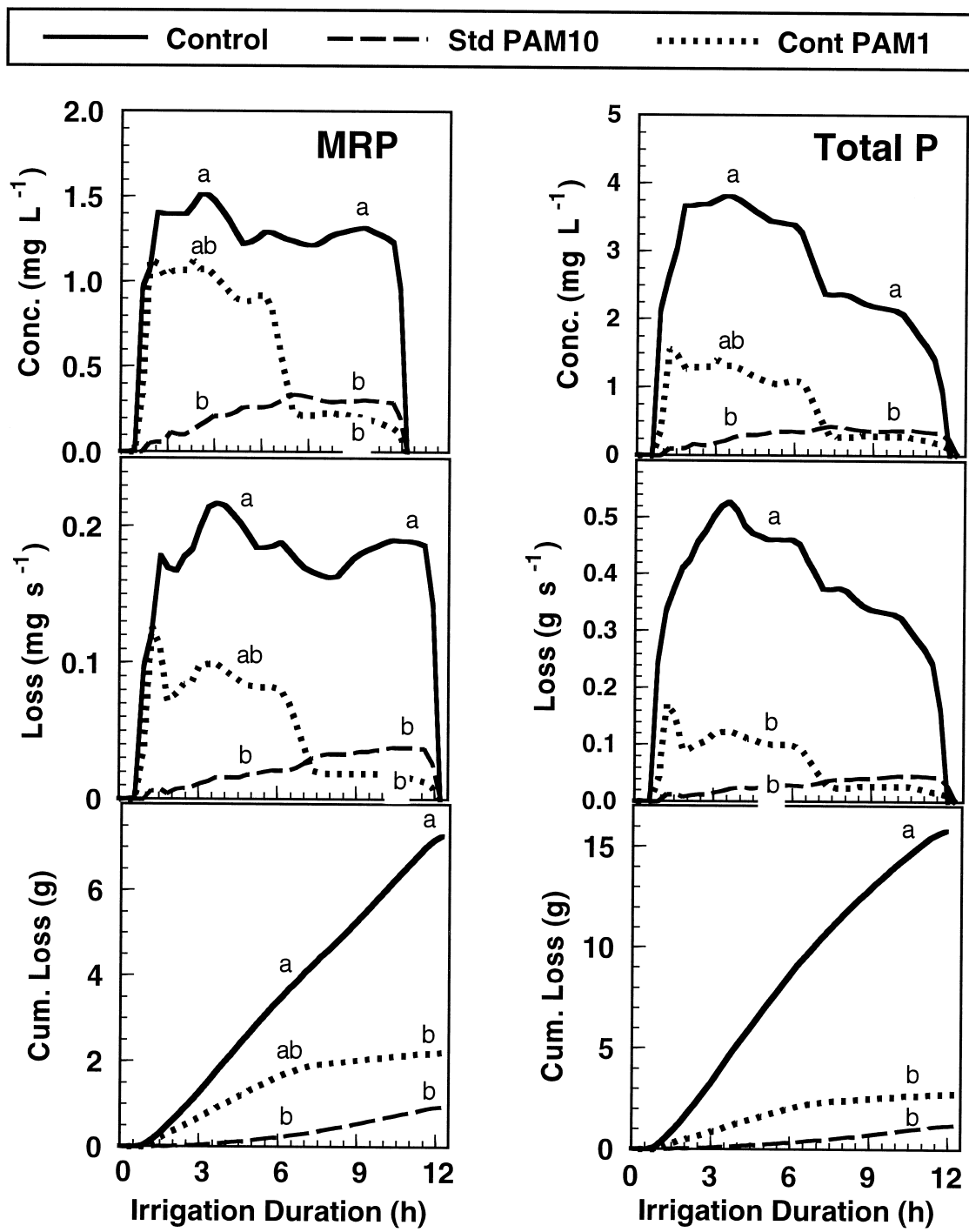

Figure 3. Molybdate-reactive-P (on left) and Total $\mathrm{P}$ (on right) concentrations and losses per furrow. Treatments included a control, $10 \mathrm{mg} \mathrm{L}^{-1}$ PAM applied during advance only (Std PAM10), and PAM applied continuously at $1 \mathrm{mg} \mathrm{L}^{-1}$ (Cont PAM1). Similar letters indicate nonsignificant differences $(\mathrm{P}=0.05)$ between treatment values. 
1998b). Note that runoff MRP concentrations responded slightly differently to sediment concentration depending on treatment. In control furrows, MRP concentrations decreased only slightly during the irrigation even though sediment concentrations had decreased by one half (Figs. 1 and 3). The change in PAM-furrow MRP relative to sediment concentrations was more proportionate. Control furrows carried more than twice as much sediment as PAM furrows. Hence, the relatively larger P enrichment ratios present in PAM furrow streams probably heightened the impact of sediment on runoff MRP, compared to control furrows.

The Std PAM10 treatment reduced runoff losses of P, and COD (organic materials) by 80 to $90 \%$, compared to untreated furrows. Polyacrylamide-induced reductions in runoff $\mathrm{MRP}$ and total $\mathrm{P}$ concentrations and mass loss reported here were similar to those observed for a southern Idaho demonstration project (Bahr and Stieber, 1996), which found that PAM reduced total $N$ lost in runoff by 69 to $95 \%$.

\section{Field Leaching}

Presented here is a preliminary analysis of a field-data set that included one partial irrigation season and two full irrigation seasons (Table 1). These data indicated no significant differences in cumulative field-wide deep percolation or $\mathrm{NO}_{3}-\mathrm{N}$ and chloride mass losses between conventional and PAM-managed irrigation furrows. Not even in 1996, when mean net infiltration of PAM furrows was permitted to exceed that of controls, did we observe significant treatment effects. Cumulative $\mathrm{NO}_{3}-\mathrm{N}$ percolation losses increased in 1997 relative to 1996 in response to the spring, 1997, urea application. Deep percolation at lower field positions was $9 \%$ of that at upper positions (data not shown).

\section{CONCLUSIONS}

The Std PAM10 treatment applied $10 \mathrm{mg} \mathrm{L}^{-1}$ anionic PAM to inflows as the furrow stream first advanced across the field. Once runoff began, untreated inflows were used to finish the irrigation. Relative to controls, PAM reduced total 12-h runoff losses of sediment by $90 \%$, organic matter losses as estimated by chemical oxygen demand by $85 \%$, total P by $92 \%$, and MRP by $87 \%$. Polyacrylamide accomplished these reductions mainly by lowering component concentrations in runoff water, but also by decreasing furrow runoff volume (i.e. increasing infiltration), especially early in the irrigation. Polyacrylamide's tendency to increase net furrow infiltration, had raised some concerns that it would increase downward translocation of soil water and nutrients. However, a subsequent percolation study showed that PAM-managed furrow irrigation did not result in an increase in 


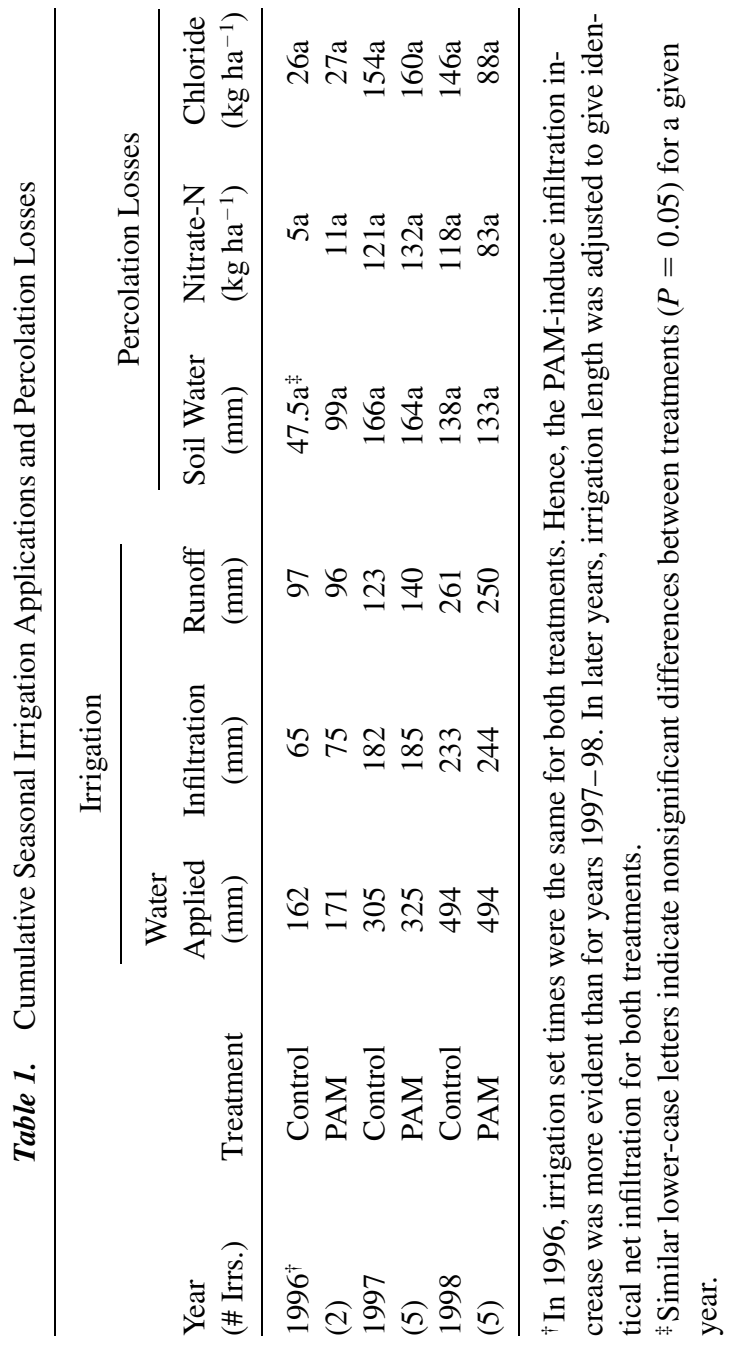


field-wide percolation losses of water or soluble nutrients such as $\mathrm{NO}_{3}-\mathrm{N}$. Polyacrylamide provides an opportunity for increasing irrigation uniformity by increasing initial furrow inflows (without attendant erosion increases). This option is not always available for other infiltration-enhancing practices, such as straw-mulching. Increasing inflows in straw-mulched furrows can result in the washing out of straw and formation of straw and sediment dams in furrows; with the latter causing flooding (Berg, 1984). Polyacrylamide-managed furrow irrigation in some Idaho soils can help increase crop nutrient-use efficiency by preventing field nutrient losses, and simultaneously protect surface water quality by reducing $\mathrm{N}, \mathrm{P}$, and organic matter concentrations in furrow runoff and return flows.

\section{ACKNOWLEDGMENTS}

This work was supported in part by a grant from CYTEC Industries, through a Cooperative Research and Development Agreement (contract 58-3K95-4-216). Comments by Drs. Mahdi Al-Kaisi, Jan Boll, and Robert Mahler on an early draft of the manuscript were greatly appreciated. We thank Dr. Anita Koehn, Mr. Ron Peckenpaugh, Mr. Jim Foerster, and Mr. Andrew Mutziger for their valuable technical assistance, and Ms. Kristen Swafford, Ms. Jamie Ward, Ms. Riqui Heinemann, and Mr. Seth Oliver for their help in the lab and field.

\section{REFERENCES}

American Public Health Association, American Water Works Association, and Water Pollution Control Federation. 1971. Oxygen demand (chemical). p. 495-499. In Anon. (ed.) Standard Methods for the Examination of Water and Wastewater. 13th ed. American Public Health Association, New York.

Bahr, G.L., and T.D. Stieber. 1996. Reduction of nutrient and pesticide losses through the application of polyacrylamide in surface irrigated crops. p. 4148. In R.E. Sojka and R.D. Lentz (ed.) Managing Irrigation-Induced Erosion and Infiltration with Polyacrylamide. Proc. Workshop, Twin Falls, ID. 6-8 May, 1996. Univ. of Idaho Misc. Publ. No 101-96. Univ. of ID, Moscow, ID.

Barvenik, F.W. 1994. Polyacrylamide characteristics related to soil applications. Soil. Sci. 158:235-243.

Berg, R.D., and D.L. Carter. 1980. Furrow erosion and sediment losses on irrigated cropland. J. Soil and Water Cons. $35: 267-270$.

Berg, R.D. 1984. Straw residue to control furrow erosion on sloping irrigated cropland. J. Soil Water Cons. 39:58-60. 
Bishop, A.A., M.E. Jensen, and W.A. Hall. 1967. Surface irrigation systems. p. 865-884. In R.M. Hagan, H.R. Howard and T.W. Edminster (ed.) Irrigation of Agricultural Lands. Agron. Monogr. No. 11, ASA, Madison, WI. Bjorneberg, D.L., D.T. Westermann, and J.K. AAse. 1999. Phosphorus dynamics in furrow irrigation water. p. 351 In 1999 Agronomy abstracts. ASA, Madison, WI.

Brown, M.J. 1985. Within-furrow erosion and deposition of sediment and phosphorous. p. . In S.A. El-Swaify, W.C. Moldenhauer and A. Low (ed.) Soil Erosion and Conservation. Soil Cons. Soc. Am., Ankeny, IA (146; $113-$ 118).

Bucks, D.A., T.W. Sammis, and G.L. Dickey. 1990. Irrigation for arid areas. p. 499-548. In G.J. Hoffman, T.A. Howell and K.H. Solomon (ed.) Management of Farm Irrigation Systems. American Society of Agricultural Engineers, St. Joseph, MI.

Carter, D.L., and J.A. Bondurant. 1976. Control of sediments, nutrients, and adsorbed biocides in surface irrigation return flows. USEPA Rep. EPA-600/276-237 (EPA-IAG-D5-F648). U.S. Gov. Print. Office, Washington,DC.

Carter, D.L., J.A. Bondurant, and C.W. Robbins. 1971. Water-soluble $\mathrm{NO}_{3}$-nitrogen, $\mathrm{PO}_{4}$-phosphorus, and total salt balances on a large irrigation tract. Soil Sci. Soc. Amer. Proc. 35:331-335.

Carter, D.L., M.L. Brown, C.W. Robbins, and J.A. Bondurant. 1974. Phosphorus associated with sediments in irrigation and drainage waters for two large tracts in southern Idaho. J. Environ. Qual. 3:287-291.

Childs, J.L, W.W. Wallender, and J.W. Hopmans. 1993. Spatial and seasonal variation of furrow infiltration. J. Irr. Drain. Eng. 119:74-90.

Fitzsimmons, D.W., G.C. Lewis, D.V. Naylor, and J.R. Busch. 1972. Nitrogen, phosphorus and other inorganic materials in waters in a gravity-irrigated area. Trans. ASAE 15:292-295.

Greenberg, A.E., L.S. Clesceri, and A.D. Eaton. 1992. Standard Methods For The Examination Of Water And Wastewater. American Public Health Association, American Water Works Association, and Water Environment Federation, Washington, DC.

Idaho Department of Health and Welfare, Division of Enviironmental Quality (IDHW-DEQ). 1994. The 1994 Idaho Water Quality Status Report. October, 1994. pp. 141.

Heathwaite, A.L., and P.J. Johnes. 1996. Contribution of nitrogen species and phosphorus fractions to stream water quality in agricultural catchments. Hydrological Processes 10:971-983.

Kemper, W.D., R. Rosenau, and S. Nelson. 1985. Gas displacement and aggregate stability of soils. Soil Sci. Soc. Am. J. 49:25-28.

Kincaid, D.C. and R.D. Lentz. 1998. An automated vacuum extraction control system for soil water percolation samplers. p. 287 In Agronomy Abstracts. ASA, Madison, WI. 
Koluvek, P.K., K.K. Tanji, and T.J. Trout. 1993. Overview of soil erosion from irrigation. Journal of Irrigation and Drainage Engineering (ASCE) 119: 929-946.

Lentz, R.D. 1995. Irrigation (Agriculture): Using polyacrylamide to control furrow-irrigation induced erosion. p. 162-165. In S.P. Parker (ed.) 1996 Yearbook of Science and Technology. McGraw-Hill, Inc., New York.

Lentz, R.D., and R.E. Sojka. 1994. Field results using polyacrylamide to manage furrow erosion and infiltration. Soil. Sci. 158:274-282.

Lentz, R.D., and R.E. Sojka. 1995. Monitoring software for pollutant components in furrow irrigation runoff. p. 123-127. In L. Ahuja, J. Leppert, K. Rojas and E. Seely (ed.) Computer Applications in Water Management, Proc. Workshop, 23-25 May, 1995. Colorado State University Water Resources Research Institute Info. Series No. 79. Colorado State University, Fort Collins, CO.

Lentz, R.D., and R.E. Sojka. 2000a. Polymer charge and molecular weight effects on treated irrigation furrow processes. Int. J. Sed. Res. (In Press)

Lentz, R.D., and R.E. Sojka. 2000b. Applying polymers to irrigation water: evaluating strategies for furrow erosion control. Trans. ASAE (Submitted).

Lentz, R.D., I. Shainberg, R.E. Sojka, and D.L. Carter. 1992. Preventing irrigation furrow erosion with small applications of polymers. Soil Sci. Soc. Am. J. 56: $1926-1932$.

Lentz, R.D., T.D. Stieber, and R.E. Sojka. 1995. Applying polyacrylamide (PAM) to reduce erosion and increase infiltration under furrow irrigation. p. 79-92. In L.D. Robertson, P. Nolte, B. Vodraska, B. King, T. Tindall, J. Romanko and J. Gallian (ed.) Proc. Winter Commodity Schools-1995. Vol. 27. University of Idaho Cooperative Extension, Moscow, ID.

Lentz, R.D., R.E. Sojka, and D.C. Kincaid. 1998a. Design and calibration of percolation samplers for measuring polyacrylamide-amended furrow-irrigation effects on drainage water quality. p. 267-276. In L.C. Brown (ed.) Proc. Seventh International Drainage Symposium, Orlando, FL 8-10 March 1998. ASAE, St Joseph, MI.

Lentz, R.D., R.E. Sojka, and C.W. Robbins. 1998b. Reducing phosphorus losses from surface-irrigated fields: emerging polyacrylamide technology. J. Environ. Qual. 27:305-312.

Letey, J. 1994. Adsorption and desorption of polymers on soil. Soil. Sci. 158: $244-248$.

Logan, T.J. 1982. Mechanisms for release of sediment-bound phosphate to water and the effects of agricultural management on fluvial transport of particulate and dissolved phosphate. Hydrobiologia 92:519-530.

Mackenzie, A.J., and F.G.J.R. Viets. 1974. Nutrients and other chemicals in agricultural drainage waters. p. . In J. Van Schilfgaarde (ed.) Drainage For Agriculture. Agronomy 17:489-511. American Society of Agronomy, Madison, WI. 
Malik, M., and J. Letey. 1991. Adsorption of polyacrylamide and polysaccharide polymers on soil materials. Soil Sci. Soc. Am. J. 55:380-383.

Mitchell, A.R. 1986. Polyacrylamide application in irrigation water to increase infiltration. Soil. Sci. 141:353-358.

Oloya, T.O., and T.J. Logan. 1980. Phosphate desorption from soils and sediments with varying levels of extractable phosphate. J. Environ. Qual. 9:525-531.

SAS Institue Inc. 1988. SAS/STAT User's Guide, Release 6.03 Edition. SAS Institute Inc., Cary, NC.

Snedecor, G.W., and W.G. Cochran. 1980. Statistical Methods. 7th ed. Iowa State University Press, Ames, IA.

Sojka, R.E., and R.D. Lentz. 1997. Reducing furrow irrigation erosion with polyacrylamide (PAM). J Prod. Agric. 10:1-2, 47-51.

Sojka, R.E., D.L. Carter, and M.J. Brown. 1992. Imhoff Cone determination of sediment in irrigation runnoff. Soil Sci. Soc. Am. J. 56:884-890.

Sojka, R.E., R.D. Lentz, C.W. Ross, T.J. Trout, D.L. Bjorneberg, and J.K. Aase. 1998a. Polyacrylamide effects on infiltration in irrigated agriculture. J. Soil and Water Cons. 53:325-331.

Sojka, R.E., R.D. Lentz, and D.T. Westermann. 1998b. Water and erosion management with multiple applications of polyacrylamide in furrow irrigation. Soil Sci. Soc. Am. J. $62: 1672-1680$.

Terry, R.E., and S.D. Nelson. 1986. Effects of polyacrylamide and irrigation method on soil physical-properties. Soil. Sci. 141:317-320.

Trout, T.J., and B.E. Mackey. 1988. Inflow-outflow infiltration measurement accuracy. Journal of Irrigation and Drainage Engineering (ASCE) 114: $256-265$.

Trout, T.J., R.E. Sojka, and R.D. Lentz. 1995. Polyacrylamide effect on furrow erosion and infiltration. Trans. ASAE 38:761-765.

Watanabe, F.S., and S.R. Olsen. 1965. Test of an ascorbic acid method for determining phosphorus in water and $\mathrm{NaHCO}_{3}$ extracts from soils. Soil Sci. Soc. Amer. Proc. 29:677-678.

Westermann, D.T., D.L. Bjorneberg, J.K. Aase, and C.W. Robbins. 1999. Soil phosphorus (P) effects on $\mathrm{P}$ losses during furrow irrigation. p. 351 In 1999 Agronomy abstracts. ASA, Madison, Wi.

Yonts, C.D., B.L. Benham, K.L. Palm, and D.L. Reichert. 1998. Influence of polyacrylamide, used in combination with surge irrigation, on irrigation performance and soil erosion. ASAE Paper No. 98-2171. St Joseph, Mich.: ASAE. 